\title{
The Cytological and Chemical Organization of the Prostatic Epithelium of Didelphis virginiana Kerr
}

\author{
JAN MARTAN ${ }^{1}$ AND JOHN M. ALLEN ${ }^{2}$ \\ Department of Zoology, The University of Michigan, \\ Ann Arbor, Michigan
}

\begin{abstract}
The prostatic complex of Didelphis virginiana Kerr has been studied by a variety of cytological and cytochemical means. Segment I was characterized by an apocrine type secretory mechanism. The apical parts of the epithelial cells, which were shed into the glandular lumen, contained vesicles which give positive cytochemical reactions for acid phosphatase, aliesterase, 5'-nucleotidase, and nucleoside diphosphatase. These vesicles also contained material which was reactive with the periodic acid-Schiff test for mucopolysaccharide and Baker's test for phospholipid. Segment II was characterized by the presence of two types of cells in the glandular epithelium. Type A cells contained large rounded secretory granules which gave positive reactions for acid mucopolysaccharides but not for proteins. Type B cells contained large elongate secretory granules which gave positive reactions for proteins but not for polysaccharides. Electronmicrographs indicated these secretory granules to have distinctive morphologies and to contain complex crystalloid material. No cells with characteristics intermediate between those of the $A$ and $B$ types were observed. Segment III of the prostatic complex was characterized by the presence of large amounts of glycogen both in the epithelial cells and within the glandular lumen. These observations indicate a remarkable degree of morphological and biochemical heterogeneity on the part of the prostatic complex of this animal.
\end{abstract}

In spite of the fact that the Virginia opossum has been widely used during more than three decades of research on problems of reproductive physiology, no modern study of the cytological organization of the prostatic complex of this animal has been carried out. Chase ('39) described the gross morphology and histological organization of the prostate gland in this form. In common with the prostate glands of other mammals, that of the opossum is of the tubulo-alveolar variety. The secretory acini are embedded in the urethral stroma and the gland is thus of the disseminate or diffuse type (Price, '63). Grossly, three regions of the gland may be recognized in adult males. Segment $I$ is the most craniad portion and is light brown in color; Segment II is the medial portion and is pink in color; and Segment III is most caudad and is dark grey in color. The histological organizations of these segments differ (Chase, '39). Underlying this histological differentiation is a series of cytological and chemical differences which we believe are unique in the area of prostatic morphology. A description of the cytological and some of the cytochemical characteristics of the three segments of the prostatic complex of Didelphis virginiana Kerr are the subject of this paper.

\section{MATERIALS AND METHODS}

The eight adult, male animals used in this study were obtained from the Carolina Biological Supply House, Elon College, North Carolina during the months of October to May. They were judged to be in a state of full reproductive development on the basis of the curvature of the prostatic urethra and by the distinctive colors of the various prostatic segments (Chase, '39).

Tissue for the following cytological and cytochemical procedures was embedded in paraffin by standard procedure: Mitochondria were visualized by Kull's aurantia method (Baker, '50) or by the methods of Mallory or Regaud (Lillie, '54) after fixation in the solution of Helly (Lillie, '54). Golgi material was stained by the Aoyama method (Lillie, '54) after fixation in $4.0 \%$ aqueous formaldehyde contain-

1 Postdoctoral Fellow, U. S. Public Health Service Training Grant 5 T1 GM 989. Present address: Department of Zoology, University of Southern Illinois, Carbondale, Illinois.

2 Work supported by U.S. Public Health Service Grant AM 5731-C2. 
ing $1.0 \%$ cadmium chloride. Glycogen was localized after freeze-substitution (Lison and Voaeker, '49) or after fixation in Bouin's fluid at $4^{\circ} \mathrm{C}$, by application of the periodic acid-Schiff (PAS) reaction (Lillie, '54) or by staining with the Best carmine procedure (Lillie, '54). Sections digested one hour at $37^{\circ} \mathrm{C}$ with malt diastase in $0.02 \mathrm{M}$ phosphate buffer at $\mathrm{pH} 6.0$ (Lillie, '54) served as controls for both procedures. Mucopolysaccharides were localized, after fixation in $4.0 \%$ aqueous formaldehyde containing $1.0 \%$ cadmium chloride, by the periodic acid-Schiff reaction (Lillie, '54), the Alcian blue test (McManus and Mowry, '60). Ribose nucleic acid was visualized by staining with Azure B (Swift, '60) after fixation in $4.0 \%$ aqueous formaldehyde containing $1.0 \%$ cadmium chloride. Sections incubated for one hour at $37^{\circ} \mathrm{C}$ in $0.01 \%$ $(\mathrm{w} / \mathrm{v})$ ribonuclease (Worthington) in $0.02 \mathrm{M}$ phosphate buffer at $\mathrm{pH} 6.0$ containing $0.8 \%(\mathrm{w} / \mathrm{v})$ sodium chloride served as controls (Lillie, '54). Protein was visualized in tissues fixed in $4.0 \%$ aqueous formaldehyde containing $1.0 \%$ cadmium chloride by the mercury bromophenol method (Pearse, '60), the ninhydrin Schiff method for protein amino groups (Pearse, '60), or the dihydroxydinaphthyl-disulfide (DDD) method for sulfhydryl groups (Pearse, '60). Secretory granules in Segment II of the prostatic complex were stained by Ludford's osmium tetroxide procedure (Lillie, '54).

Phospholipids were visualized in frozen sections by the procedure of Baker ('46), by staining with Sudan Black B in propylene glycol (Pearse, '60), or by staining with Luxol Fast Blue MBS (Pearse, '55).

Tissues for electron microscopic study were fixed in Palade's fixative (Pease, '64) and embedded in Epon.

Tissue used for the localization of various enzymes was quenched in isopentane cooled to a temperature of approximately $-150^{\circ} \mathrm{C}$ in a bath of liquid nitrogen. These tissues were sectioned at $6-8 \mu$ in a microtome cryostat maintained at $-20^{\circ} \mathrm{C}$. Unless otherwise stated, all enzyme localizations were made with sections which had been postfixed in acetone for one hour at $0^{\circ} \mathrm{C}$ or with sections cut from tissues previously fixed in $4.0 \%$ formaldehyde for 12 hours at $4^{\circ} \mathrm{C}$ and washed in water for 12 hours at $4^{\circ} \mathrm{C}$. The following methods for enzyme localization were used: Acid phosphatase was localized by the method of Gomori ('52) using sodium $\beta$-glycerophosphate as the substrate. Acetone and formaldehyde fixed sections were incubated 5 to 120 minutes at $37^{\circ} \mathrm{C}$. Control sections were preincubated 30 minutes at $0^{\circ} \mathrm{C}$ in $0.002 \mathrm{M} \mathrm{D}$-tartaric acid in $0.05 \mathrm{M}$ acetate buffer at $\mathrm{pH}$ 7.0. These sections were then incubated at $37^{\circ} \mathrm{C}$ in standard reaction mixtures to which $0.002 \mathrm{M}$ D-tartaric acid had been added. These sections showed no reaction product after incubation for two hours. Other sections were incubated in reaction mixtures containing no substrate. After treatment with ammonium sulfide, these sections showed no reaction product. Paraffin sections of tissues fixed in $4.0 \%$ formaldehyde containing $1.0 \%$ cadmium chloride were subjected to identical treatment (after dewaxing) and also showed no reaction product after treatment with ammonium sulfide. The diazonium coupling procedure of Barka (Barka and Anderson, '63) was also used for the localization of acid phosphatase. Sections were incubated 2 to 8 hours at $25^{\circ} \mathrm{C}$ in reaction mixtures containing Naphthol AS MX phosphate. The distribution of acid phosphatase by this method was identical to that observed with the Gomori method. Alkaline phosphatase was localized by a diazonium coupling procedure (Pearse, '60) using sodium a-naphthyl acid phosphate as the substrate and the stable diazoate of 5-chloro-o-toluidine (Fast Red TR, C.I. 37080). Sections were incubated at $25^{\circ} \mathrm{C}$ for 5 to $30 \mathrm{~min}$ utes. Aliesterase was localized according to Pearse ('60) using a-naphthyl acetate as the substrate and the stable diazonium salt of o-amino-azotoluine (Fast Blue B, C.I. 37235) as the coupling agent. Formaldehyde fixed sections were incubated 8 to 30 minutes at $25^{\circ} \mathrm{C}$. Leucine aminopeptidase was localized by the method of Nachlas, Crawford and Seligman ('57) using L-leucyl- $\beta$-naphthylamide as the substrate and the stable diazotate of o-aminoazotoluine as the coupling agent. Sections were incubated 10 to 50 minutes at $25^{\circ} \mathrm{C}$. Five nucleotidase was localized by the method of Wachstein and Meisel (Pearse, 
'60) using adenosine-5'-phosphate as the substrate. Sections were incubated five minutes to two hours at $37^{\circ} \mathrm{C}$. Nucleoside diphosphatase was localized by the method of Novikoff and Goldfischer ('61) using thiamine pyrophosphate as the substrate. Formaldehyde fixed sections were incubated 15 and 30 minutes at $37^{\circ} \mathrm{C}$. Succinic dehydrogenase was localized according to the method of Nachlas et al. ('57). Acetone fixed sections were incubated 10 to 15 minutes at $37^{\circ} \mathrm{C}$. Controls for all enzyme localizations, except where otherwise noted, consisted of the omission of substrate material. In all cases, this control showed no reaction product.

\section{RESULTS}

\section{Segment I}

The most characteristic morphological feature of Segment I of the prostatic complex was the presence of large cytoplasmic globules in the lumina of the secretory acini (fig. 1). These globules appeared to be derived by a process of apocrine secretion from the epithelium of this segment. The epithelium lining the acini contained cells ranging from cuboidal to low columnar in height and was typified by the ragged basal remnants of cells which had lost their apical cytoplasm to the luminal contents (figs. 1 and 2 ). In certain instances it was possible to see the columnar cells in the process of extruding the apical cytoplasm into the acinar lumen. The presence of luminal globules and the fringed appearance of the secretory epithelium were noted under all conditions of preparation employed. It is unlikely that the loss of the apical cytoplasm and the formation of Iuminal globules were due to damage during preparation of the material.

Intact epithelial cells were characterized by accumulations of PAS positive and diastase resistant granules in the apical portions of the cytoplasm (fig. 4). The luminal margins of these cells possessed an Alcian blue reactive fringe (fig. 4). The ragged remnants of epithelial cells which had lost their apical cytoplasm were also Alcian blue positive. Following staining with the Aoyama technique, granules in the apical portions of the epithelial cells were seen (fig. 6). The Aoyama reaction also displayed a compact Golgi complex which was situated in the midthird of the cytoplasm, just superior to the large vesicular nucleus. Ergastoplasm, identified by Azure B staining and ribonuclease digestion, was concentrated in the basal third of the cytoplasm of epithelial cells. Mitochondria were concentrated in the apical reaches of these cells. The Baker acid hematein reaction for phospholipid demonstrated mitochondria and also gave dense staining in apically situated granules (fig. 5).

Aliesterase activity was localized in the apical portions of the epithelial cells. In this locale two types of reaction were noted. One of these was diffuse and appeared to be associated with no particular cellular structure while the other was localized to granules situated in the apical portions of these cells. Nucleoside diphosphatase and $5^{\prime}$-nucleotidase showed similar distribution patterns in these epithelial cells. Tissues treated for the localization of acid phosphatase by both the Gomori method and the diazonium coupling method showed a sharp localization of the enzyme to apically situated granules (figs. 1,2 , and 3 ). In these cases there was no diffuse reaction except in the case of sections incubated for very long times.

The cytology and the cytochemical reactions of the luminal cytoplasmic globules were identical in all respects to those described above for the apical portions of the cells lining the glandular acini (figs. $1-6)$.

The fact that many of the cytochemical tests applied to this segment demonstrated a localization of the reaction product to apically situated granules in intact epithelial cells, or to granules situated within the extruded cytoplasmic droplets suggests a common structural association. However, differences in the sizes of the particles under different conditions of preparation makes this point difficult, if not impossible, to determine. The granules observed after the application of the PAS reaction and, Baker's acid hematein test were large and of a similar size. Aliesterase, acid phosphatase, and nucleoside diphosphatase were localized in granules of approximately the same size as the two 
previously noted reactions. The Aoyama reaction and tests for the localization of 5 -nucleotidase showed the distribution of reaction product in much smaller granules.

\section{Segment II}

The epithelium lining the acini of Segment II of the prostatic complex contained two types of cells which could be distinguished on the basis of their size, their cytochemical reactions and the morphology of their cytoplasmic granules.

Type A cells were tall columnar elements containing large numbers of round granules scattered throughout the cytoplasm (fig. 7). The granules of this cell type reacted strongly with the PAS technique (fig. 8). The granules within the type A cells also gave positive reactions following staining with Alcian blue and the colloidal iron method of Müller. Following application of the PAS reaction with subsequent reaction by Müller's colloidal iron method these granules appeared red in the central area and were surrounded by a blue-green halo (fig. 10). The mercury-bromophenol, the Schiff-ninhydrin, Millon's, and the DDD methods produced either negative or just perceptable reactions in these granules (fig. 9). These granules stained less strongly than the granules of " $B$ " cells (see below) following treatment with Ludford's osmic acid method (fig. 7).

Type B cells were also columnar in form but were less elongate than the Type A cells. The cytoplasm of these cells was filled with fusiform granules (fig. 7 ). The cytochemical reactions of these granules were largely the converse of the granules contained within the A cells. The granules of the B cells reacted only faintly with the PAS reaction and gave negative tests following staining with Alcian blue and Müller's colloidal iron method (fig. 10). Strong staining was noted in these granules after application of the ninhydrinSchiff, mercury bromophenol, Millon's, and the DDD reactions (fig. 9). The reaction of these elongate granules was much more intense following Ludford's osmic acid technique than was that of the granules in the type A cells (fig. 7). The granules of these cells also stained strongly following application of the Kull, Mallory, or Regaud techniques for demonstration of mitochondria (figs. 11 and 14). Differential demonstration of the granular components of the two cell types could be made conveniently by refixation of sections of formaldehyde fixed tissues for three hours in Helly's fluid or in 5.0\% mercuric chloride and then by staining with the PAS reaction followed by Mallory's phosphotungstic acid hematoxylin stain (figs. 8 and 13). Under these conditions the granules of the type A cells were stained red and those of the type B cells were stained purple.

Neither type of granule was stained following treatment of sections with Sudan Black B or with the Baker test for phospholipid. Likewise, neither type of granule was reactive with any of the enzyme cytochemical tests applied (see below).

Both types of epithelial cells yielded positive reactions for the presence of nucleoside diphosphatase (fig. 17), 5'-nucleotidase (fig. 18), aliesterase, and leucine amino peptidase. In all instances, these enzymes were localized in a network which was distributed throughout the cytoplasms of the A and B cells. This network clearly outlined the unstained secretory granules. Both cell types gave positive reactions for the presence of succinic dehydrogenase. This enzyme displayed a distribution identical to that of mitochondria as visualized by routine methods. Alkaline phosphatase and acid phosphatase were not detected in either cell type.

Tissue stained by the Aoyama method showed the presence of a large, typical Golgi complex in the supranuclear cytoplasm of both types of cells (fig. 16). This method also produced a net-like distribution of reduced silver (fig. 15). This distribution of metal was identical to the net-like distribution of the enzymes mentioned above. Sections stained for visualization of RNA showed a similar net-like distribution of dye (fig. 12). Mitochondria were visible in the cytoplasm of both cell types after appropriate staining (fig. 11). In type $B$ cells identification of mitochondria was complicated by the presence of the secretion granules which also stained with methods for the demonstration of mitochondria. 
Both cell types could be identified in electron micrographs by the typical structure of their granules. The type A-cells contained numerous granules bound by a single smooth membrane (fig. 23). The granules contained moderately electron dense filamentous material and a small peripheral dense disc. The granules of Bcells were also surrounded by a single membrane. They contained electron dense elongate bodies composed of densely packed, parallel threads or filaments (figs. 19 and 21 ). These bodies, when sectioned vertical to the long axis, were roughly hexagonal (fig. 20). The matrix around these bodies was of low electron density (fig. 20). Samples obtained from the periphery of the second segment showed cells containing many rounded granules which were highly heterogeneous in their morphology (fig. 19). They ranged from dense, apparently homogeneous bodies to less dense structures which contained a series of cylindrical, often parallel elements. High magnification electron micrographs indicated that the structure of these elements was regular and in cross section consisted of a peripheral dense circle surrounding a central dense mass (fig. 22). The dense granules appeared to be filled by densely packed cylinders.

The luminal contents of this portion of the prostate gave positive reactions with the PAS test, Müllers colloidal iron reaction, the Alcian blue test as well as with the Schiff-ninhydrin reaction, the DDD reaction and the mercury bromophenol test. This material, therefore, appears to be a conglomeration of protein and polysaccharide derived, presumably, from the granules of the A and $B$ types of cells.

\section{Segment III}

The acinar epithelium of Segment III was composed of cuboidal cells which contained large masses of material giving a cytochemical reaction for glycogen (figs. 28 and 29). This material was strongly reactive with both the PAS reaction and Best's glycogen stain. Globules of glycogen also appeared in the lumina of the acini. In all instances the cytochemical reaction was abolished by diastase digestion.
Aqueous homogenates of this prostatic segment were extracted with $30 \%$ potassium hydroxide at $100^{\circ} \mathrm{C}$ (Seifter et al., '50) and the glycogen was precipitated in 95\% ethanol. Samples of this precipitate were hydrolyzed in $1.0 \mathrm{~N}$ hydrochloric acid at $100^{\circ} \mathrm{C}$ for six hours. This hydrolysate was deionized by pyridine extraction (Malpress and Morrison, '49). Samples of this deionized material were spotted on Whatman no. 1 paper and subjected to descending chromatography using a butanol:acetic acid:water solvent $(4: 1: 5)$ (Block et al., '58). The dried chromatograms were developed with a silver nitrate reagent (Trevelyan et al., ' 50 ) for reducing sugars. These samples contained material with a migration identical to that of samples of pure glucose. Quantitative analysis of samples of this prostatic segment by the anthrone method (Seifter et al., '50) indicated a glycogen content of 2.0 gm per $100 \mathrm{gm}$ of wet starting tissue.

The distribution of ergastoplasm, Golgi material and mitochondria in the epithelial cells of this segment was governed by the size of the glycogen mass. In the majority of cells, the ergastoplasm, as visualized by Azure B staining, was distributed as a diffuse net in the peripheral cytoplasm bordering the central glycogen mass. Occasionally the glycogen mass was ringed by Azure B stainable material. The distribution of Golgi material as visualized by the Aoyama method, was similar to that of the ergastoplasm. Mitochondria were found above and around the glycogen mass.

Phospholipids, as revealed by Baker's acid hematein reaction and Luxol Fast Blue MBS, were concentrated in the apical cytoplasm of epithelial cells in this segment. The amorphous secretion mass in the gland lumen also reacted with these tests (figs. 26 and 27).

Acid phosphatase was present in the epithelial cells of this segment of the prostate and was restricted to large granules or vesicles located randomly in the cytoplasm (fig. 25). The amorphous mass of material in the gland lumen also gave a positive reaction for this enzyme (fig. 24). Similar patterns of distribution were noted following application of the diazonium coupling reaction. 
Nucleoside diphosphatase activity was restricted to the apical and lateral margins of the epithelial cells. These preparations suggested that this enzyme was present in, or was closely associated with, the cellular membrane (fig. 30).

Aliesterase was localized to one or two large cytoplasmic bodies situated in the mid-portions of the epithelial cells (fig. 31). The nature of the structure with which the enzyme was associated is unknown. The distribution of this enzyme was dissimilar to that of acid phosphatase.

Succinic dehydrogenase activity mimicked the distribution of mitochondria as noted by classical techniques.

Cytochemical tests for alkaline phosphatase and $5^{\prime}$-nucleotidase were negative

\section{DISCUSSION}

The prostatic complex of Didelphis virginiana emerges from these studies as a remarkably heterogeneous organ from both morphological and chemical viewpoints. Each segment has a characteristic secretory product, a characteristic cellular morphology, and a characteristic cytochemistry. The cytochemical and cytological complexity observed in the prostate of the Virginia opossum is greater than that reported for other mammals (Price, '63).

On the basis of cytochemical analysis it appears that the secretory products of Segment I are partly enzymatic. In this segment, aliesterase, acid phosphatase, nucleoside diphosphatase, and 5'-nucleotidase were observed in the luminal contents. In all instances these enzymes were present within vesicles or granules contained in the extruded apical portions of the epithelial cells. It is clear that the mode of secretion in this segment of the prostate of the opossum is apocrine. No other instance of apocrine secretion has been reported to occur in prostatic tissue.

The granules within the extruded cytoplasmic globules also reacted with the PAStest, the Aoyama silver stain, and the Baker acid hematein reaction. They may, therefore, be presumed to contain polysaccharide and phospholipid. The nature of the material responsible for the Aoyama reaction is unknown. The association of acid phosphatase with particles containing polysaccharide and having a capacity for combination with bivalent metal suggests them to be lysosomal in nature (Koenig, '62). The extrusion of these particles, along with their enveloping cytoplasm, constitutes further cytological evidence for a secretory function of lysosomal vesicles (Novikoff, '63). The physiological role of the enzymes thus liberated into the glandular lumen is unknown for this species. Acid phosphatase and 5'-nucleotidase are well known seminal constituents in other mammalian groups (Mann, '64). The former enzyme may be involved in the release of choline from glycerylphosphorylcholine or phosphorylcholine (Mann, '64).

The morphological and cytochemical observations reported above are compatible with the interpretation that two cell types are present in the epithelium of Segment II. Although the relative frequencies of the $A$ and $B$ cells varied according to their position in this segment there was no evidence for a transformation of one cell type into the other. In no instance were cells observed which showed a mixture of the two types of granules. On the basis of the above cytochemical analysis, we feel the granules of the A-type cells contain large amounts of polysaccharide. Failure of diastase to remove the PAS-reactive material of these granules obviates the presence of glycogen. Reaction of this granule type with both the Alcian blue test and Müller's colloidal iron test indicates the presence of acidic groups and makes possible the tentative identification of the reactive material as an acid mucopolysaccharide. The B-type cells were strongly reactive with various tests for the presence of protein. The limited discriminatory power of current cytochemical tests for protein makes an attempt at further classification pointless. The apparent high protein content of these granules suggests a similarity to the zymogen granules of various secretory cells. None of the enzymatic tests applied, however, gave positive reactions in either type of granule. Cytochemical tests for enzymes are limited in scope and it is possible that these granules contain enzymatic activity which was not detected by our methods.

The granules of the A and B cell types also differed morphologically. These dif- 
ferences were apparent at the level of the light microscope and were even more striking when viewed with the electron microscope. Both types of granules had a complex internal morphology composed of a regular array of filamentous material of crystalloid appearance. The studies of Hruban and Swift ('64), on the electron microscopic morphology of enzyme (and other) crystalloids show striking similarities to the bodies observed in some granules of the two cell types reported here. Similar crystalloid inclusions in secretory granules of prostatic Segment II of the opossum have been briefly reported by Ladman and Soper ('63).

The presence of multiple cell types in prostatic epithelium is unusual. However, Brandes et al. ('62) have reported the identification of two cell types in the dorsal prostate of the rat. In these studies, identification was based on differences in electronmicroscopic morphology; cytochemical differences were not reported. The only instance of a similar degree of cytochemical heterogeneity known to us was reported by Mann ('54) in the seminal vesicle of the bull. In this instance three cell types were stated to be present and these differed in their cytochemical reactions.

The high glycogen content of Segment III is a unique observation in terms of prostastic biochemistry. No other reports of distinctive glycogen levels in prostate are known to us. The presence of this sugar polymer in the epithelium and in the lumen of Segment III appears significant. Fructose is the predominant seminal sugar in the majority of mammals (Mann, '64). Its secretion is the result of biochemical and endocrinological specialization of various cells of the male reproductive glands. Seminal fructose is normally produced from blood glucose but also may be formed from tissue glycogen (Mann, '64). It is possible that the high levels of glycogen found in Segment III may represent depots of carbohydrate available for fructose formation either intracellularly or in the gland lumen. In this latter case, the cellular glycogen may be secreted and then converted to glucose within the gland lumen. Either device would serve to sequester metabolizable carbohydrate for use by sperm cells. It is intriguing to speculate that the enzymes for luminal conversion might represent significant secretory products of Segments I and II.

The observations reported here establish a high degree of specialization on the part of the segments of the prostatic complex of Didelphis virginiana. There is little doubt that this specialization is related to the metabolic requirements of the sperm cells of this animal. These requirements are, unfortunately, unknown. However, the prostatic complex of this animal would appear to afford an excellent opportunity to study the biochemical attributes of prostatic secretion.

\section{ACKNOWLEDGMENT}

We wish to thank Dr. Zdenek Hruban, Department of Pathology, The University of Chicago, Chicago, Illinois for preparing the electron micrographs shown in figures 19-23.

\section{LITERATURE CITED}

Baker, J. R. 1946 The histochemical recognition of lipine. Quart. Jour. Micro. Sci., 87: 441-470.

- 1950 Cytological Technique, 3rd Ed., London, Methuen, $211 \mathrm{pp}$.

Barka, T., and P. J. Anderson 1963 Histochemistry, New York, Harper and Row, Inc., $660 \mathrm{pp}$.

Block, R. J., E. L. Durrum and G. Zweig 1958 A Manual of Paper Chromatography and Paper Electrophoresis, 2nd Ed., New York, Academic Press Inc., 710 pp.

Brandes, D., F. Györkey and D. P. Groth 1962 Fine structural and histochemical study of the effect of castration on the rat prostatic complex. I. The coagulating gland. Lab. Invest., 11: $339-350$.

Chase, E. B. 1939 The reproductive system of the male opossum, Didelphis virginiana Kerr and its experimental modification. J. Morph., 65: 215-239.

Gomori, G. 1952 Microscopic Histochemistry, Chicago, The University of Chicago Press, $273 \mathrm{pp}$.

Hruban, Z., and H. Swift 1964 Uricase: Localization in hepatic microbodies. Science, 146: 1316-1318.

Koenig, H. 1962 Histological distribution of brain gangliosides: lysosomes as glycolipoprotein granules. Nature, 195: 782-784.

Ladman, A. J., and E. H. Soper 1963 Cytological observations on intragranular inclusion bodies in the prostate of the opossum. Anat. Rec., 145: 364.

Lillie, R. D. 1954 Histopathological Technic and Practical Histochemistry, New York, The Blakiston Company, 501 pp. 
Lison, L., and R. Vokaer 1949 Sur la detection histochimique du glycogene des cellules vaginales chez la femme. Ann. Endocrinol., 10; 66-72.

Malpress, F. H., and A. B. Morrison 1949 Use of pyridine in the de-ionization of solutions for paper chromatography. Nature, 164: 963.

Mann, T. 1954 The Biochemistry of Semen, London, Methuen, $240 \mathrm{pp}$.

1964 The Biochemistry of Semen and of the Male Reproductive Tract, New York, John Wiley and Sons, Inc., $493 \mathrm{pp}$.

McManus, J. F. A., and R. W. Mowry 1960 Staining Methods, New York, Paul B. Hoeber, Inc., $423 \mathrm{pp}$.

Nachlas, M. M., D. T. Crawford and A. M. Seligman 1957 The histochemical demonstration of leucine aminopeptidase. J. Histochem. Cytochem., 5: 264-278.

Nachlas, M. M., K. C. Tsou, E. Souza, C. S. Chang and A. M. Seligman 1957 Cytochemical demonstration of succinic dehydrogenase by the use of a new p-nitrophenyl substituted ditetrazole. J. Histochem. Cytochem., 5: 420-436.

Novikoff, A. B. 1963 Lysosomes in the physiology and pathology of cells: Contributions of staining methods. In: Lysosomes, Ciba Foundation Symposium, A. V. S. deReuck and M. P. Cameron, Eds., Boston, Little Brown and Co., p. 36-77.
Novikoff, A. B., and S. Goldfischer $1961 \mathrm{Nu}$ cleoside diphosphatase activity in the Golgi apparatus and its usefulness for cytological studies. Proc. Nat. Acad. Sci. U.S., 47: 802810.

Pearse, A. G. E. 1955 Copper phthalocyanins as phospholipid stains. J. Path. Bact., 70: 554-557.

1960 Histochemistry, 2nd Ed., Boston, Little Brown and Co., 998 pp.

Pease, D. C. 1964 Histological Techniques for Electron Microscopy, 2nd Ed., New York, Academic Press, Inc., 381 pp.

Price, D. 1963 Comparative aspects of development and structure in the prostate. In: Biology of the Prostate and Related Tissues, E. P. Vollmer, Ed., Bethesda, Maryland, National Cancer Institute, Monograph no. 12.

Seifter, S., S. Dayton, B. Novic and E. Muntwyler 1950 The estimation of glycogen with the anthrone reagent. Arch. Biochem., 25: 191200.

Swift, H. 1960 Cytochemical techniques for nucleic acids. In: The Nucleic Acids Vol. II, E. Chargraff and J. N. Davidson, Eds., New York, Academic Press, p. 51-92.

Trevelyan, W. E., D. P. Practer and J. S. Harrison 1950 Detection of sugars on paper chromatograms. Nature, 166: 444-445.

\section{PLATE 1}

\section{EXPLANATION OF FIGURES}

1 Distribution of acid phosphatase in Segment I of the prostatic complex. The reaction product is restricted to vesicles in the apical portions of intact epithelial cells and to similar vesicles in the extruded masses of cytoplasm located in the acinar lumen. The presence of large numbers of oval cytoplasmic masses in the acinar lumen is indicative of an apocrine type of secretory mechanism. Gomori method, $4.0 \%$ formaldehyde prefixation, $8 \mu$ cryostat section, 20 minutes, $37^{\circ} \mathrm{C}$. $\times 1,500$.

2 Identical to figure 1 except that tissue was postfixed in acetone for one hour at $0^{\circ} \mathrm{C}$. Vesicular localization of the reaction product is seen in the apical portions of intact epithelial cells but the cytoplasmic fragments in the acinar lumen are largely destroyed.

3 Identical to figure 1 except that the tissue was preincubated in $0.05 \mathrm{M}$ acetate buffer containing $0.002 \mathrm{M}$ D-tartaric acid for 30 minutes at $0^{\circ} \mathrm{C}$ and was incubated in a reaction mixture containing $0.002 \mathrm{M}$ b-tartaric acid. Under these conditions no reaction product was produced. 
PROSTATIC EPITHELIUM

Jan Martan and John M. Allen
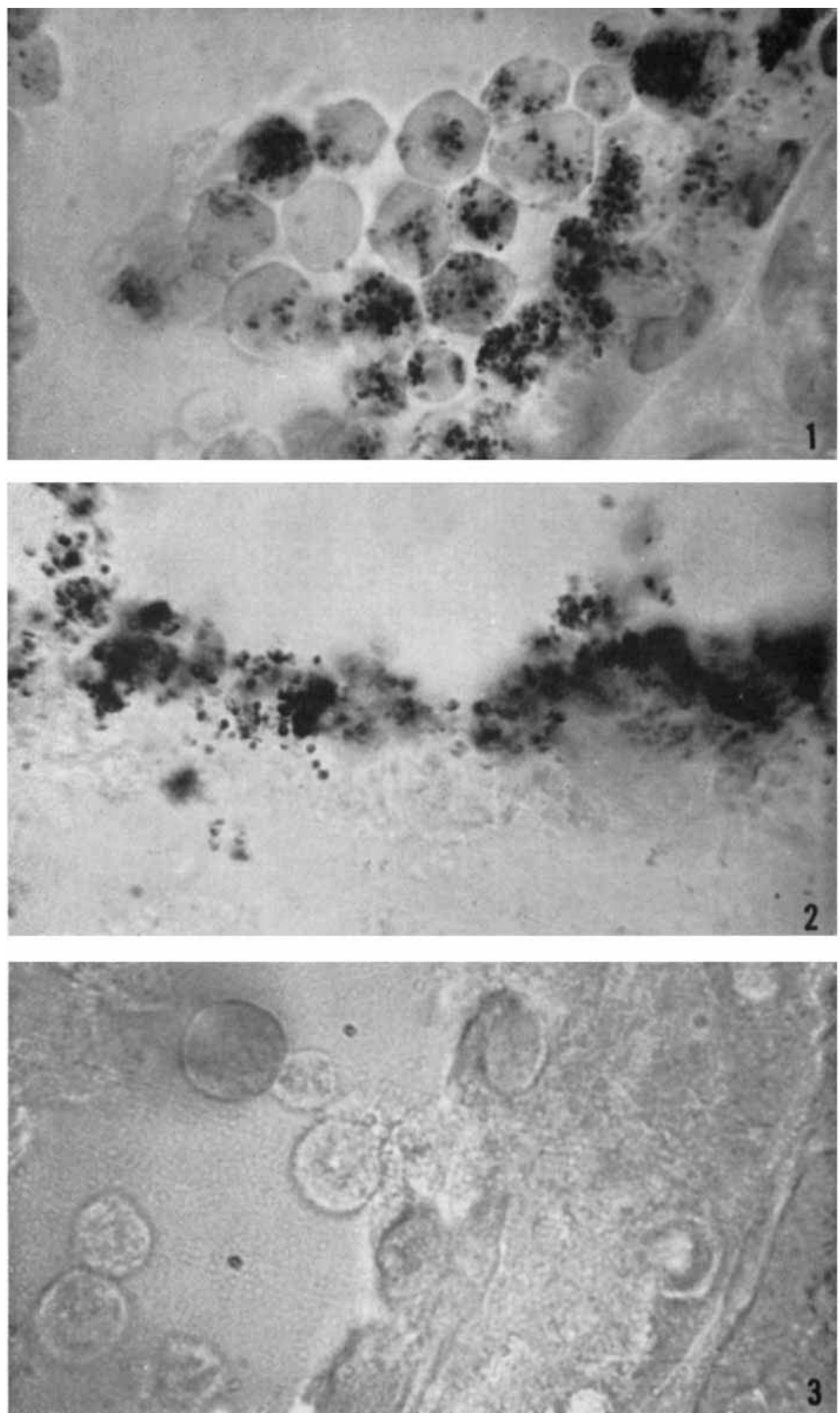
PLATE 2

EXPLANATION OF FIGURES

4 Distribution of periodic acid-Schiff reactive, diastase resistant material in Segment $I$ of the prostatic complex. The reaction product is restricted to vesicles located in the apical portions of intact epithelial cells and to similar vesicles in cytoplasmic fragments in the luminal portions of the gland. Periodic acid-Schiff-Alcian blue, fixed in $4.0 \%$ formaldehyde containing $1.0 \%$ cadmium chloride, paraffin embedded, $6 \mu$ section. $\times 1,500$.

5 Distribution of phospholipid in Segment $I$ of the prostatic complex. Reaction product is restricted to vesicles located in the apical portions of intact epithelial cells and to vesicles in extruded cytoplasmic fragments. Baker's acid hematein test, $4.0 \%$ formaldehyde containing $1.0 \%$ calcium chloride, cryostat section, $8 \mu . \times 1,500$.

6 Distribution of reduced silver following application of the Aoyama procedure. Reaction product is distributed in vesicles located in the apical parts of intact epithelial cells and in similar vesicles in extruded cytoplasmic bodies. Fixed in $4.0 \%$ formaldehyde containing $1.0 \%$ cadium chloride, paraffin embedded, $6 \mu . \times 1,500$. 

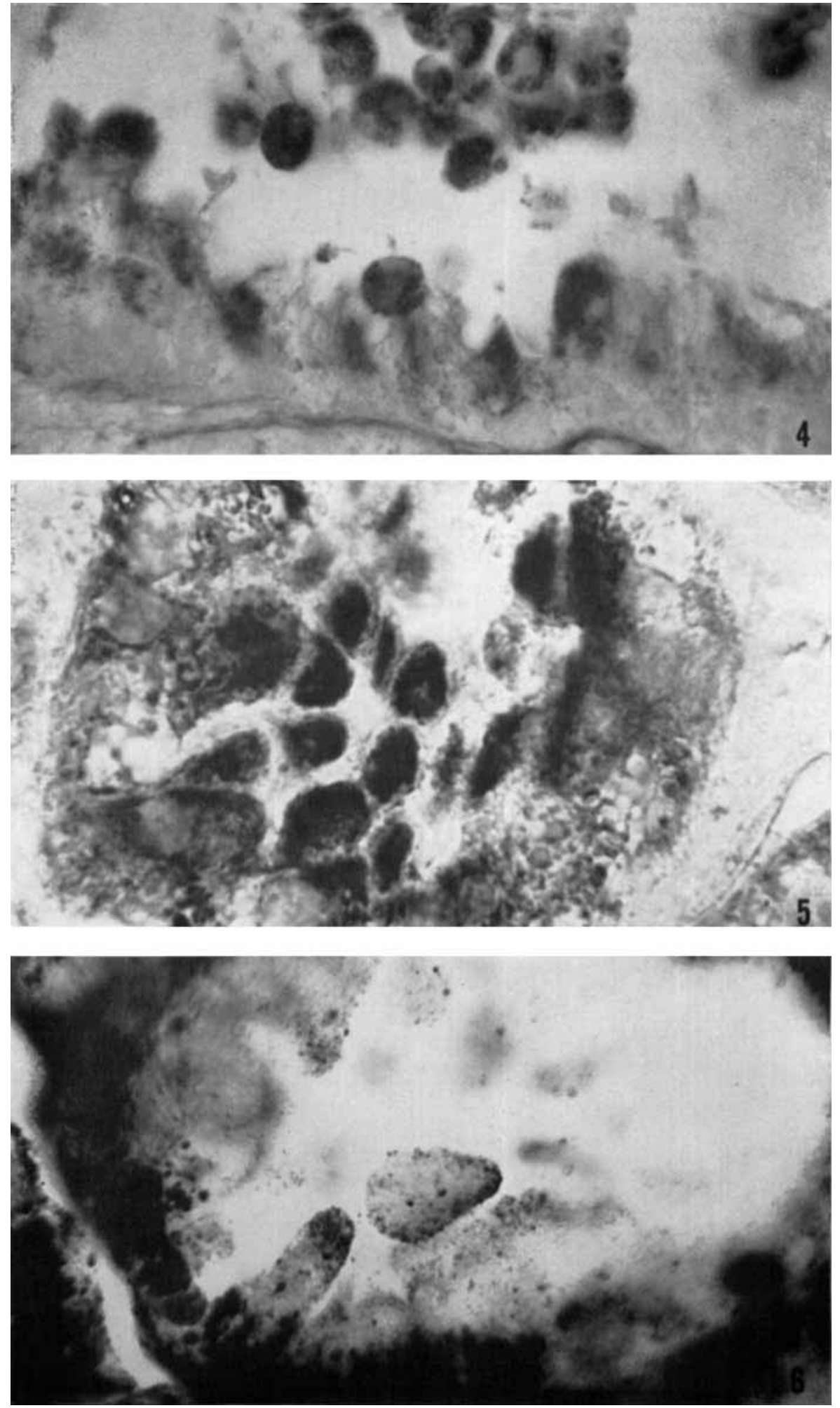


\section{PLATE 3}

EXPLANATION OF FIGURES

7 " $A$ " and " $\mathrm{B}$ " cells in the epithelium of Segment II of the prostatic complex. Type " $A$ " cells are characterized by the presence of rounded secretory granules and a greater height than the type " $B$ " cells which are typified by the presence of elongate secretory granules. Ludford osmium tetroxide method, paraffin embedded, $3 \mu . \times 1,750$.

8 Differential staining of " $\mathrm{A}$ " and " $\mathrm{B}$ " cells following fixation in $4.0 \%$ formaldehyde containing $1.0 \%$ cadmium chloride and refixation (after sectioning and mounting) for three hours in $5.0 \%$ mercuric chloride at $50^{\circ} \mathrm{C}$. The rounded granules in the " $A$ " cells stain red after treatment with the periodic acid-Schiff procedure while the elongate " $B$ " cells stain purple after treatment with Mallory's phosphotungstic acid hematoxylin. Paraffin embedded, $2 \mu . \times 1,750$.

9 The elongate granules of the " $\mathrm{B}$ " cells are reactive after mercurybromophenol procedure for the demonstration of protein. The granules of the larger "A" cells are unreactive. Four per cent formaldehyde fixation, paraffin embedded, $3 \mu . \times 1,750$.

10 Following the application of a combined periodic acid-Schiff-colloidal iron reaction, the elongated granules of the " $B$ " cells are barely reactive but the rounded granules of the "A" cells show a strong periodic acid-Schiff reaction in their central area and a strong peripheral reaction wtih colloidal iron. Fixed in $4.0 \%$ formaldehyde, paraffin embedded, $3 \mu$, $\times 1,750$.

11 Elongate granules in " $B$ " cells show a strong reaction following application of Regaud's mitochondrial stain. Granules in type " $A$ " cells are unstained but mitochondria are visible. Tissue processed prior to staining as specified for figure $8.1 \mu$. $\times 1,750$.

12 Distribution of ergastoplasm in a net-like formation in both " $\mathrm{A}$ " and "B" cells Azure B, $4.0 \%$ formaldehyde fixation, paraffin embedded, $3 \mu$. $\times 1,750$. 
PROSTATIC EPITHELIUM

Jan Martan and John M. Allen
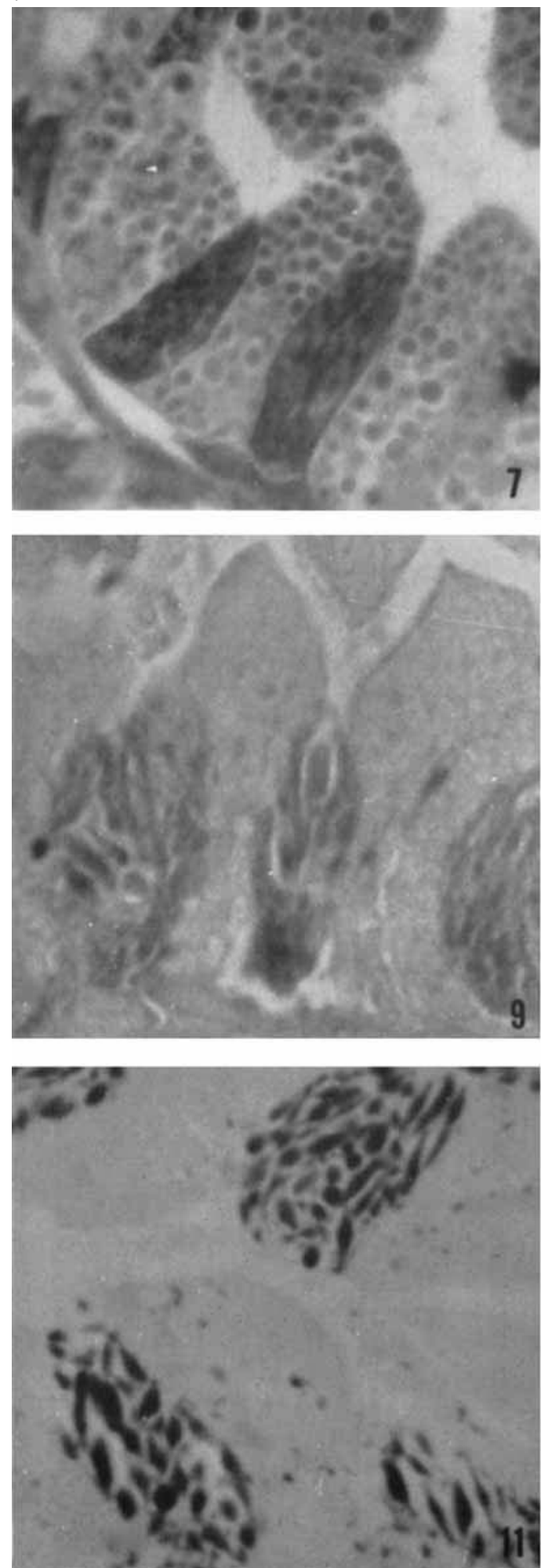

PLATE 3
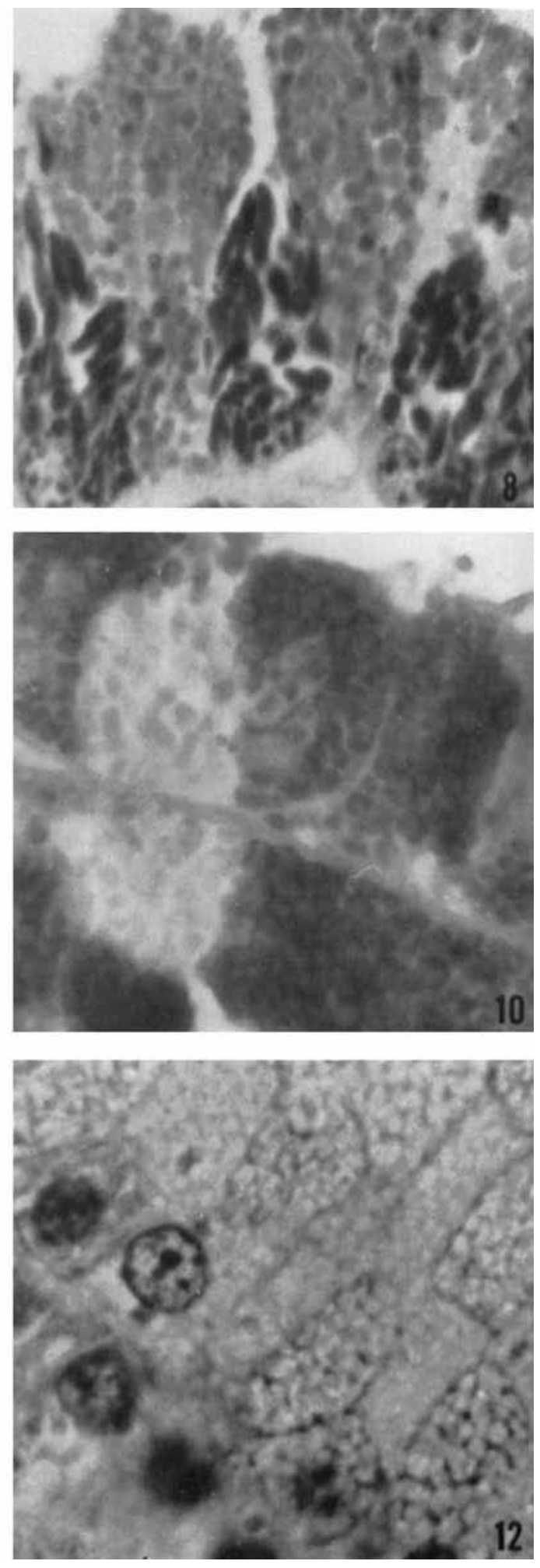
PLATE 4

\section{EXPLANATION OF FIGURES}

13 Distribution of "A" and " $B$ " cell types in the epithelium of Segment II. Darkly stained " $B$ " cells have granules densely stained by the Mallory phosphotungstic acid technique and the lighter " $A$ " cells contain granules stained by the periodic acid-Schiff method. In the luminal portions of the gland extruded secretory product can be identified. The amorphous material in the lumen is reactive with the periodic acid-Schiff test and is presumably derived from the " $A$ " cells, while the dark more granular material stains similarly to the granules contained within the " $B$ " cells and is probably derived from them. Tissue preparation identical to that used for figure $8,2 \mu$. $\times 640$.

14 Elongate granules in " $B$ " cells are densely stained following application of Kull's stain while the granules of the " $A$ " cells remain colorless. Tissue preparation identical to that used for figure $8,2 \mu$. $\times 1,750$.

15 Net-like distribution of reduced silver in both cell types following application of the Aoyama method. Fixed in $4.0 \%$ formaldehyde containing $1.0 \%$ cadmium chloride, paraffin embedded, $5 \mu . \times 1,750$.

16 Large Golgi-like masses are visible in some epithelial cells of both types following application of the Aoyama method. Preparation as specified for figure $15 . \times 1,750$.

17 Nucleoside diphosphatase activity is distributed in a net-like fashion in both " $A$ " and " $B$ " type cells (" $A$ " cell illustrated). The secretory granules are negative. There is a particularly dense reaction in the region of the plasma membrane. Novikoff-Goldfischer method, thiamine pyrophosphate as substrate, $8 \mu$ cryostat section, prefixed 12 hours in $4.0 \%$ formaldehyde at $4.0^{\circ} \mathrm{C}, 15$ minutes incubation at $37^{\circ} \mathrm{C}$. $\times 1,750$.

185 -nucleotidase activity is distributed in a net-like pattern in both " $A$ " and " $B$ " type cells (" $A$ " cells illustrated). The secretory granules are unreactive. Dense accumulation of the reaction product is present in the region between contiguous epithelial cells. Wachstein-Meisel method, adenosine $5^{\prime}$-phosphate as substrate, $8 \mu$ cryostat section, prefixed 12 hours in $4.0 \%$ formaldehyde at $4^{\circ} \mathrm{C}, 15$ minutes incubation at $37^{\circ} \mathrm{C} . \times 1,750$. 
PROSTATIC EPITHELIUM

Jan Martan and John M. Allen
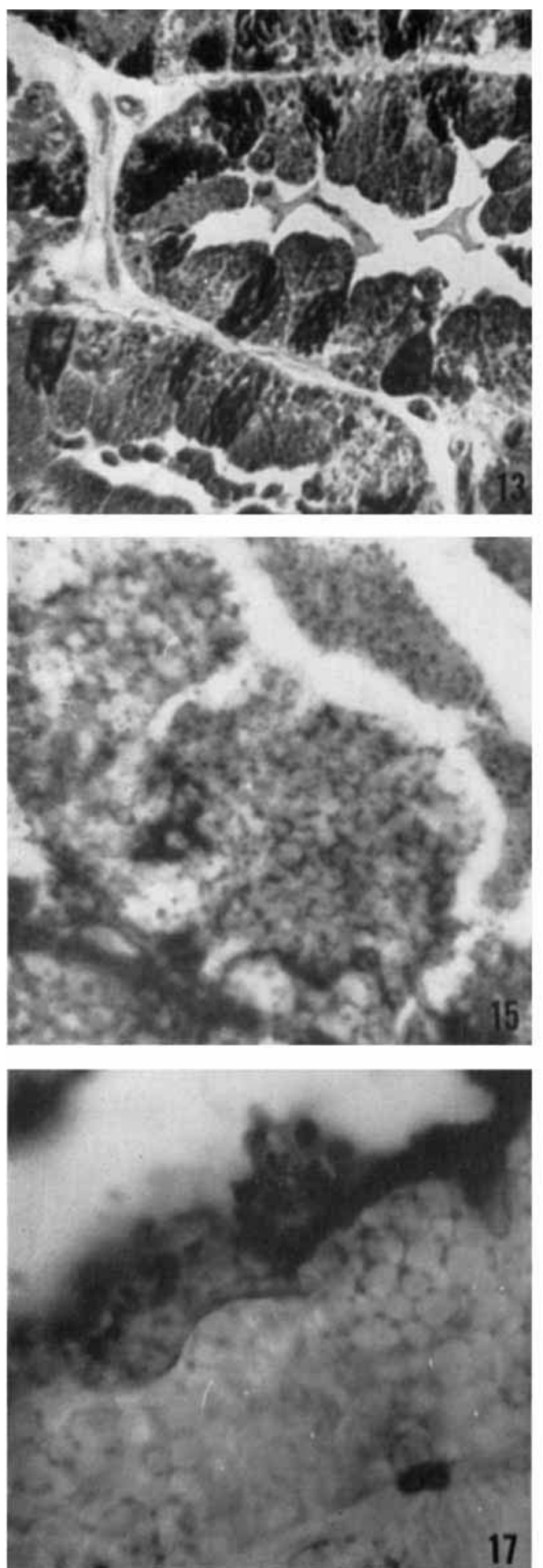
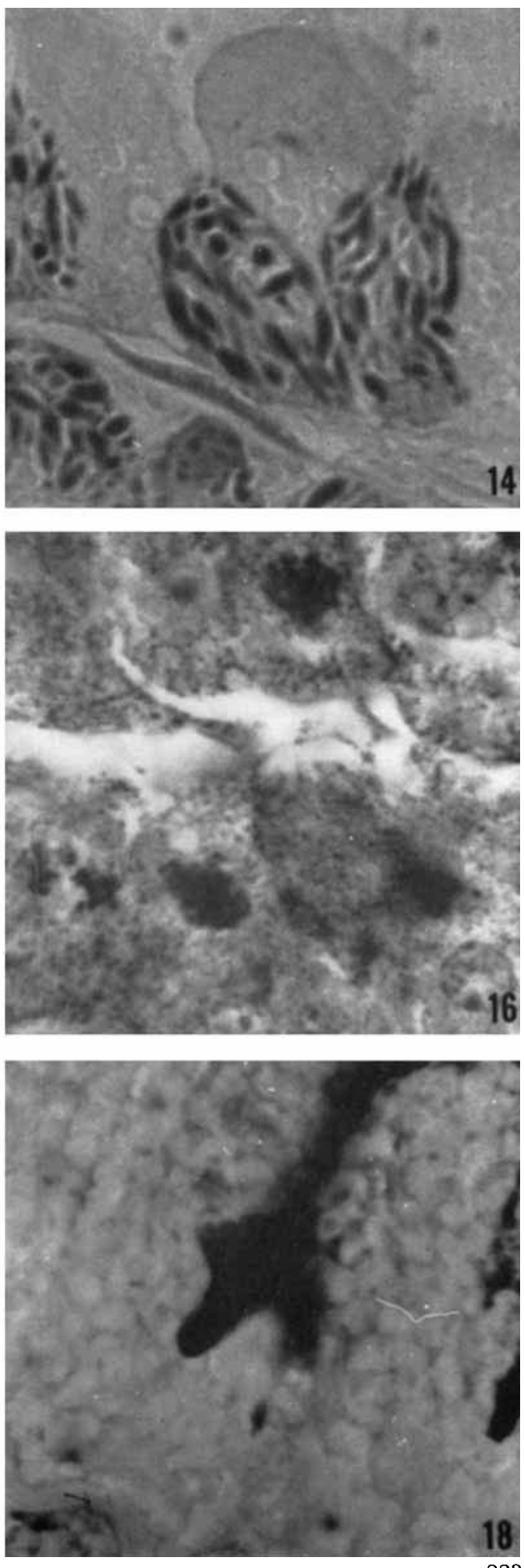
PLATE 5

EXPLANATION OF FIGURES

19 Portions of type "A" cell (left) and type "B" cell (right) from the peripheral portion of the second segment. The elongate dense secretory granules of the "B" type cells are clearly visible. The secretory granules of the " $A$ " type cell are heterogeneous in nature and contain lamellar arrays (arrows) in certain instances. Electron micrograph, Palade's fixation, Epon embedment. $\times 13,000$.

20 Dense secretory material of type " $B$ " cells shows a hexagonal profile when cut in cross section. The dense structures are contained within less dense granular bodies which are surrounded by smooth membranes. Note the fibrillar nature of the dense structures. Preparation as for figure 19 . $\times 18,000$.

21 Longitudinal section of secretory granule of type "B" cell showing the closely packed parallel fibrils. Preparation as for figure 19. $\times 16,000$.

22 Central portion of a secretory granule of a type "A" cell from the peripheral portion of the second segment. This central mass appears to be composed of masses of Iongitudinal structures (seen here in cross section) delimited by tubule-like or rod-like elements surrounding a central dense mass. This structure is probably present in granules similar to those designated by arrows in figure 19. Preparation as for figure $19 . \times 120,000$.

23 Typical granule from a type " $A$ " cell from the midportion of the second segment. Dense discoid structure is seen at the periphery. The granule is filled by fine moderately dense fibrils. Preparation as for figure 19 . $\times 33,000$. 

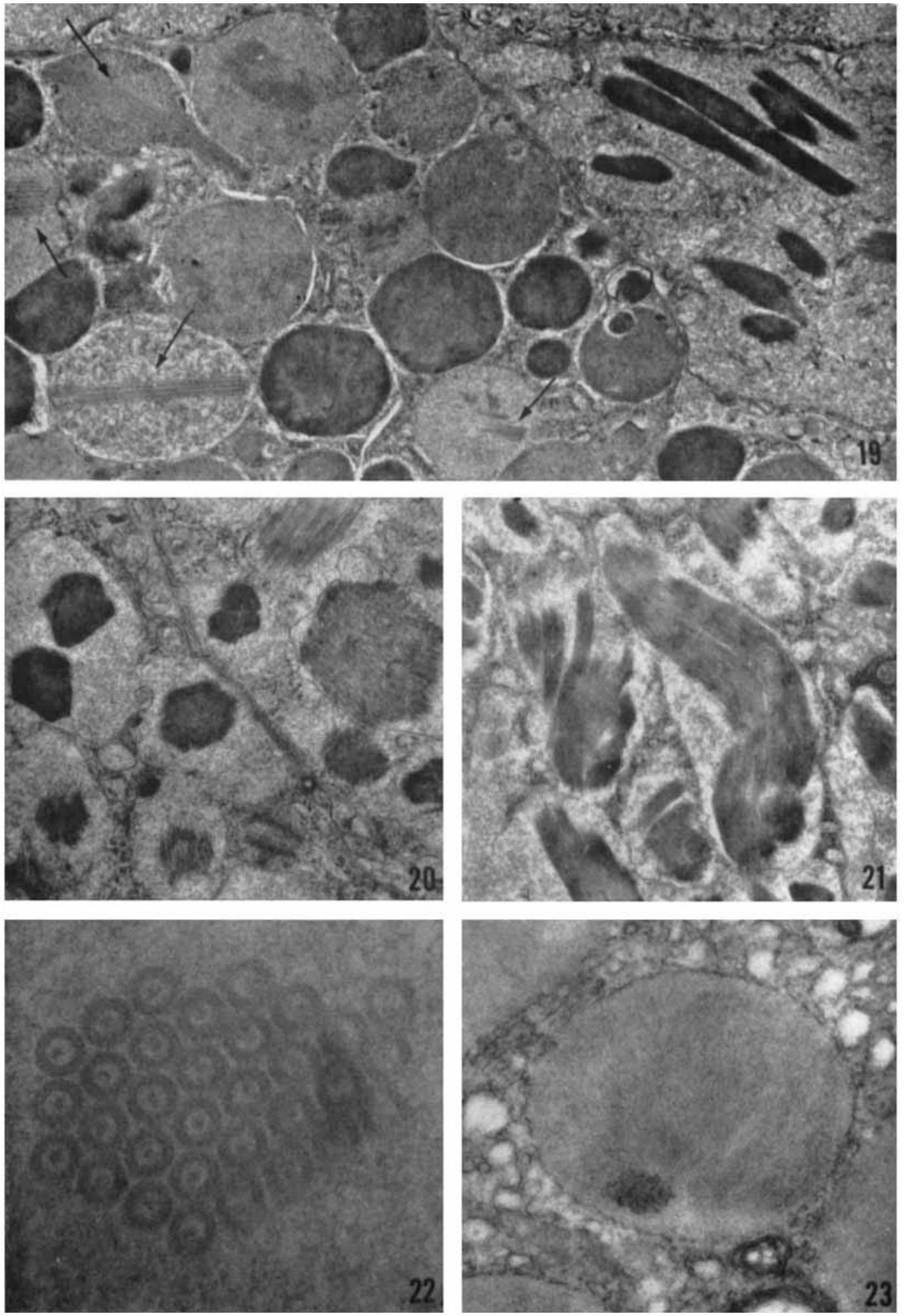
PLATE 6

\section{EXPLANATION OF FIGURES}

24 Acid phosphatase activity localized within the acinar lumina of Segment III. Gomori method, $\beta$-glycerophosphate, $8 \mu$ frozen section, postfixation in cold acetone, incubated 20 minutes at $37^{\circ} \mathrm{C} . \times 175$.

25 Identical to figure 24 but $\times 700$. Epithelial cells are negative save for scattered granules.

26 Luminal contents of acini of Segment III stain strongly with Luxol Fast Blue MBS suggesting the presence of phospholipid material. Fixed in $4.0 \%$ formaldehyde containing $1.0 \%$ cadmium chloride, paraffin embedded, $3 \mu$ section. $\times 175$.

27 Luminal contents in acinus of Segment III showing a positive reaction with the Baker acid hematein test for phospholipid. The large clear vesicles probably represent glycogen deposits. Baker acid hematein reaction, $8 \mu$ frozen section. $\times 700$. 
PROSTATIC EPITHELIUM

Jan Martan and John M. Allen
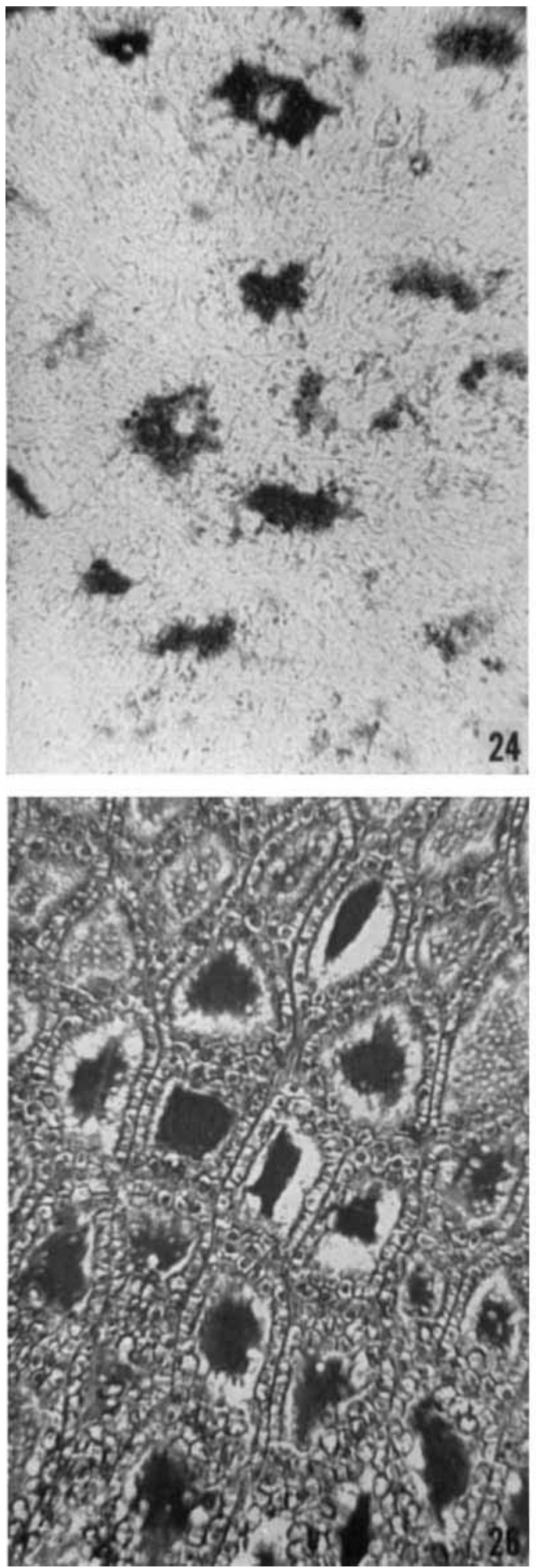

PLATE 6
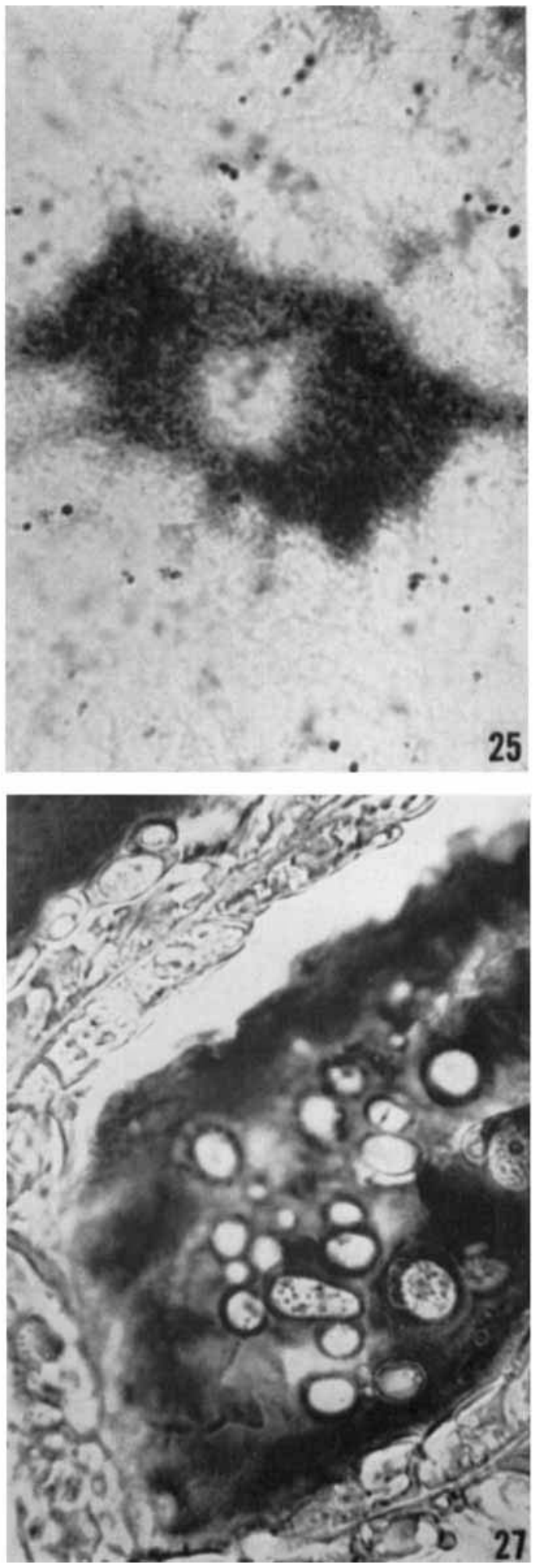


\section{PLATE 7}

28 Distribution of glycogen in Segment III of the prostatic complex. Dense accumulations of this material are seen in the epithelium and a large dense mass is present in the acinar lumen. Periodic acid-Schiff reaction, hematoxylin counterstain, Bouin fixation, $8 \mu$ frozen section. $\times 700$.

29 Identical to figure 28 but with omission of hematoxylin counterstain. Large numbers of periodic acid-Schiff reactive globules are present in the acinar lumen. $\times 700$.

30 Nucleoside diphosphatase activity in the epithelium of Segment III. The enzyme appears to be distributed in the apical cytoplasm and in the area of the cell membrane. Prefixation in cold $4.0 \%$ formaldehyde, $8 \mu$ frozen section, Novikoff-Goldfischer method, thiamine pyrophosphate as substrate, incubated 15 minutes at $37^{\circ} \mathrm{C}, \times 700$.

31 Distribution of non-specific esterase in epithelium of Segment III. The enzyme produced reaction product is localized to large granules of unknown nature. Prefixation in $4.0 \%$ formaldehyde, $8 \mu$ frozen section, a-naphthol acetate, Fast Blue B, incubated ten minutes at $25^{\circ} \mathrm{C} . \times 640$. 

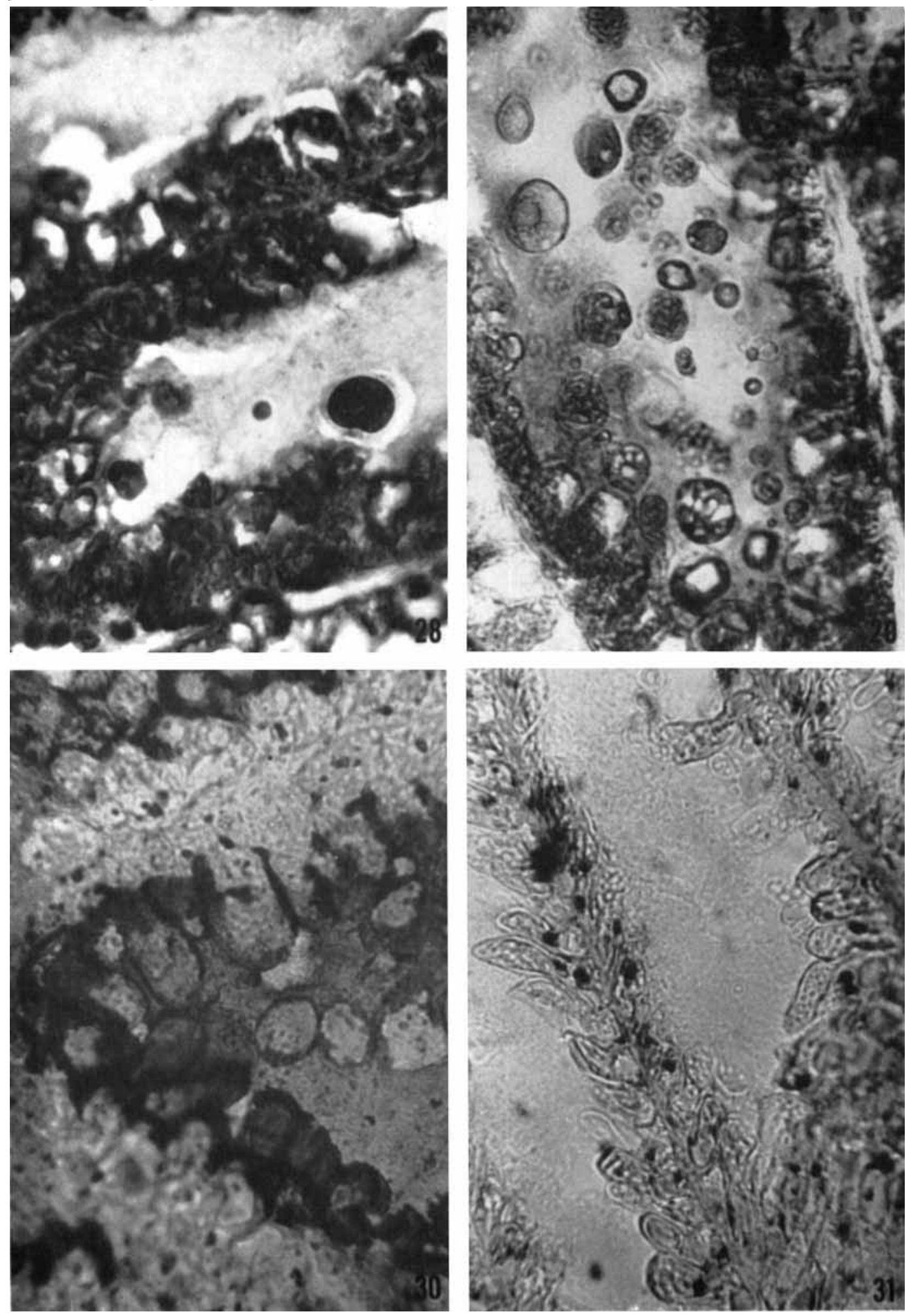